\title{
Analisis Usaha Kacang Hijau dalam Meningkatkan Pendapatan Petani di Desa Gunung Sari
}

\author{
Desi Wulandari ${ }^{1}$, M. Syahrun², Yohanes Emanuel Besin ${ }^{3}$ \\ ${ }^{1}$ Pendidikan Ekonomi, Ikip Muhammadiyah Maumere \\ e-mail: echywulandarizaenal13@gmail.com \\ 2 Pendidikan Ekonomi, Ikip Muhammadiyah Maumere \\ e-mail: torighgifari@gmail.com \\ ${ }^{3}$ Pendidikan Ekonomi, IKIP Muhammadiyah Maumere \\ e-mail: besinemanuel@ymail.com
}

\begin{abstract}
Mung beans are a type of crops that are widely known in the tropics, the production of green beans as a processed food material for high protein vegetable food and plays a role in developing small and medium industries. Gunung Sari Village, Alok Subdistrict, Sikka Regency, on average farmers use their own agricultural land for green bean business. The purpose of this study is to determine the role and efforts of green bean business farmers, and also to find out the amount of net income of farmers in Gunung Sari Village, Alok District, Sikka District from the results of expenditures reduced by the gross acceptance of farmers, and to determine the feasibility of green bean farming. This type of research used in this study is a qualitative research with a descriptive approach, this research was conducted for one month starting from December 27, 2019 to January 26, 2020. Based on the results of the study, the amount of green bean farm income Rp244,738,000 with an average of Rp6 . 118,850 from the farmers expenditure of $R p .14,292,000$ with an average of $R p .357,300$ minus gross receipts of $R p$. 259,050.00 with an average of $R p .6,476,250$. The average value of $R / C$ ratio of green bean farming is 18.12. From the $R / C$ ratio value obtained, the green bean farming in Gunung Sari Village, Alok Subdistrict is very profitable and worth the effort.
\end{abstract}

Keywords: farmer income, green bean business

\begin{abstract}
Abstrak
Kacang hijau adalah tanaman sejenis palawija yang dikenal luas di daerah tropis, produksi kacang hijau sebagai bahan olahan bahan pangan berprotein nabati tinggi dan berperan dalam menumbuh kembangkan industri kecil maupun menengah. Desa Gunung Sari Kecamatan Alok Kabupaten Sikka, ratarata petani menggunakan lahan pertanian sendiri untuk usaha kacang hijau. Adapun penelitian ini bertujuan untuk mengetahui peran dan upaya petani
\end{abstract}

Desi Wulandari - Analisis Usaha Kacang Hijau dalam Meningkatkan Pendapatan Petani di Desa Gunung Sari 
usaha kacang hijau, dan juga mengetahui besarnya pendapatan bersih para petani di Desa Gunung Sari Kecamatan Alok Kabupaten Sikka dari hasil pengeluaran di kurangi dengan penerimaan kotor petani, serta mengetahui kelayakan usahatani kacang hijau. Jenis penelitian yang digunakan dalam penelitian ini adalah penelitian kualitatif dengan pendekatan deskriptif, penelitian ini dilakukan selama satu bulan terhitung mulai tanggal 27 Desember 2019 sampai dengan 26 Januari 2020. Berdasarkan hasil penelitian, besarnya pendapatan usaha tani kacang hijau Rp244.738.000 dengan rata-rata Rp6.118.450 dari hasil pengeluaran petani sebesar Rp14.292.000 dengan ratarata Rp357.300 dikurangi dengan penerimaan kotor sebesar Rp259.050.00 dengan rata-rata Rp6.476.250. Nilai rata-rata $\mathrm{R} / \mathrm{C}$ ratio dari usahatani kacang hijau senilai 18.12. Dari nilai R/C ratio yang di peroleh maka usahatani kacang hijau di Desa Gunung ari Kecamatan Alok sangat menguntungkan dan layak untuk di usahakan.

\section{Kata kunci : pendapatan petani, usaha kacang hijau}

\section{PENDAHULUAN}

Negara Indonesia merupakan negara agraris yang jumlah penduduknya sebagian besar bermata pencaharian dalam bidang pertanian. Bidang pertanian merupakan suatu bidang yang kegiatan produksi dasarnya ialah proses pertumbuhan hewan dan tumbuh-tumbuhan untuk memenuhi kebutuhan manusia (Rahim dan Hastuti, 2008).

Sektor pertanian juga memegang peran penting dalam strategi perekonomian dan cukup memberi kontribusi yang baik untuk perekonomian nasional. Selain itu juga membantu dalam kehidupan pokok masyarakat. Peranan sektor pertanian sebagai pemasok bahan pangan, bahan baku industri, pakan dan bio-energi, sumber pendapatan nasional, dan lain sebagainya (Kementerian Pertanian, 2012).

Peran dan upaya petani sangat diperlukan dalam menigkatkan produktivitas tanaman kacang hijau baik dari kualitas maupun dari kuantitas. Upaya memelihara atau menjaga ketahanan tanaman kacang hijau, petani dapat melakukan beberapa tahapan diantaranya pemilihan benih, penyiangan, penyemprotan, panen dan pasca panen. Selain itu pada dasarnya seorang petani harus memiliki pengetahuan agar dapat memodifikasi lahan pertanian dengan tujuan meningkatkan pendapatan petani secara akumulatif serta meminimalisir biaya-biaya produksi. Menurut 
Rodjak (2006) petani sebagai unsur usaha tani yang memegang peranan penting dalam pemeliharaan tanaman atau ternak agar dapat tumbuh dengan baik. Petani yang dimaksud disini adalah orang yang bercocok tanam hasil bumi atau memelihara tanaman dengan tujuan memperoleh kehidupan dari kegiatan usahatani.

Kacang hijau bernilai ekonomis yang tinggi sehingga tanaman tersebut bisa dapat berkontribusi terhadap kehidupan sosial masyarakat yang berada didaerah yang berlahan kering. Kacang hijau dapat tumbuh di daerah yang beriklim tropis juga, dan baik pada tanah dengan $\mathrm{pH}$ tanah antara 5,5 sampai 6,5 dan pemeberian pupuk dianjurkan untuk tanaman ini adalah $50 \mathrm{~kg}$ urea, SP-36 $75 \mathrm{~kg}$ dan $50 \mathrm{~kg}$ KCI (Purwono dan Hartono, 2005).

Kacang hijau mempunyai beberapa kelebihan jika dibandingkan dengan tanaman kacang-kacangan lainnya dan tergolong sebagai tanaman yang memiliki tingkat kebutuhan yang cukup tinggi. Selain sebagai pendapatan masyarakat, petani juga sering mengolah berbagi macam olahan makanan kacang hijau ini seperti bubur kacang hijau, isian kue dan juga sayuran, karena tanaman ini mempunyai nilai gizi tinggi. Bentuk produknya sebagai biji ialah salah satu keuntungan yang bisa di simpan dengan mudah dan tahan lama.

Desa Gunung Sari merupakan desa kecil yang terletak di kepulauan Flores, Kecematan Alok Kabupaten Sikka yang mempunyai 3 dusun diantaranya dusun Waniama, dusun Ngolo dan dusun Siaga yang dimana penduduknya memenuhi kebutuhan hidup sehari-hari dengan bekerja sebagai petani. di Desa ini juga tergabung dalam kelompok tani yang berjumlah 14 kelompok tani, tujuan adanya kelompok tani membuat keuntungan besar untuk para petani disana, keuntungan yang dimaksudkan adalah Petani sering mendapatkan penyuluhan tentang cara bertani yang baik dan menghasilkan produksi kacang hijau yang berkualitas disertai dengan pelatihan dan mengetahui tinggi rendahnya harga jual maupun beli kacang hijau. Dengan adanya kelompok tani, petani mudah mendapatkan benih bantuan dari pemerintah lewat daftar Calon Petani/Lokasi dalam kegiatan pengembangan 
benih tersebut melalui anggaran APBN. Berdasarkan uraian tersebut, motivasi peneliti dalam melakukan penelitian dengan judul "Analisis Usaha Kacang Hijau Dalam Meningkatkan Pendapatan Petani Di Desa Gunung Sari”, untuk mengetahui pendapatan bersih yang dihasilkan setiap petani di Desa Gunung Sari dalam memenuhi kebutuhan sehari-hari dari usahatani kacang hijau.

\section{METODE PENELITIAN}

Jenis penelitian yang digunakan adalah kualitatif dengan pendekatan deskriptif. Penelitian kualitatif merupakan suatu penelitian yang berlandaskan pada filsafat post positivisme, digunakan untuk meneliti pada kondisi objek yang alamiah. Dalam analisis data tersebut digunakan teknik analisis deskriptif kualitatif yaitu setelah semua data yang diperlukan telah terkumpul kemudian disusun dan diklasifikasikan, selanjutnya dianalisis dan diinterpretasikan dengan kata-kata sedemikian rupa untuk menggambarkan obyek-obyek penelitian di saat penelitian dilakukan, sehingga dapat diambil kesimpulan (Sugiyono, 2009). Sumber data yang digunakan dalam penelitian yaitu sumber data primer dan sekunder.

Data Primer merupakan data yang langsung diberikan kepada pengumpul data. Sumber data primer diperoleh melalui kegiatan wawancara dengan subjek penelitian dan melakukan pengamatan secara langsung dilapangan. Sedangkan data sekunder merupakan sumber data yang tidak langsung memberikan data kepada pengumpul data, misalnya melalui orang lain atau dokumen (Sugiyono, 2016).

Teknik pengumpulan data yang digunakan dalam penelitian ini berupa observasi, wawancara dan dokumentasi. Observasi digunakan untuk mengamati cara kerja petani menanam hingga memanen tanaman kacang hijau, wawancara digunakan untuk mendapatkan informasi dengan cara mengajukan beberapa pertanyaan kepada 40 orang responden mengenai tingkat produksi dan pendapatan petani kacang hijau, sedangkan dokumentasi digunakan untuk memproleh data dari tempat penelitian berupa profil desa.

Teknik analisis data yaitu menggunakan analisis biaya produksi usahatani, analisis penerimaan, Analisis kelayakan R/C (Return Cost Ratio), dari data-data 
yang telah diperoleh, dapat dilakukan perhitungan sederhana yang dianalisis. Untuk menganalisis pendapatan bersih petani usaha kacang hijau di Desa Gunung Sari, maka dapat digunakan rumus sebagai berikut:

1. Analisis Biaya Produksi Usahatani

Biaya merupakan total pengeluaran dalam bentuk uang yang digunakan untuk menghasilkan suatu produk selama satu periode. Dalam biaya yang dimaksud adalah sarana produksi yang habis terpakai misalnya, bibit, pupuk dan obatobatan, lahan serta biaya daro alat-alat produksi (Syafruwadi et al., 2012).

Biaya produksi merupakan semua faktor produksi yang digunakan baik dalam bentuk benda maupun jasa selama produksi berlangsung. Menurut Wanda (2015) biaya produksi merupakan keseluruhan biaya yang dikeluarkan untuk memenuhi kebutuhan produksi dapat berupa barang maupun jasa.

Biaya produksi dapat dihitung menggunakan rumus sebagai berikut:

$$
\mathrm{TC}=\mathrm{TVC}+\mathrm{TFC}
$$

Keterangan :

$\mathrm{TC}=$ Total Biaya

TVC $=$ Total Biaya Variabel

TFC = Total Biaya Tetap

\section{Analisis Penerimaan}

Penerimaan dalam usaha tani adalah total pemasukan yang diterima oleh oleh petani dari kegiatan produksi yang sudah dilakukan dan menghasilkan uang yang belum dikurangi oleh biaya-biaya yang dikeluarkan selama produksi (Husni etal., 2014). Penerimaan juga merupakan hasil perkalian antara hasil produksi yang telah dihasilkan selama produksi dengan harga jual produk (Ambarsari et al., 2014).

Penerimaan yang diperoleh dari usahatani kacang hijau dapat dihitung dengan rumus:

$$
\mathrm{TR}=\mathrm{P} \cdot \mathrm{Q}
$$

Keterangan:

$\mathrm{TR}=$ Total Penerimaan 


$$
\begin{aligned}
& \mathrm{P}=\text { Harga Jual Per Unit } \\
& \mathrm{Q}=\text { Jumlah Produksi }
\end{aligned}
$$

3. Analisis Pendapatan

Pendapatan bersih usahatni adalah selisi antara total penerimaan usahatani dengan total biaya yang dikeluarkan untuk produksi. Besar kecilnya pendapatan usahatani dapat digunakan untuk melihat keberhasilan usaha (Soekartiwi, 2006).

Pendapatan bersih atau keuntungan yang di peroleh yang di peroleh dari suatu kegiatan usahatani kacang hijau dapat dihitung dengan rumus:

$$
\pi=\mathrm{TR}-\mathrm{TC}
$$

Keterangan:

$\pi=$ Pendapatan Usahatani

$\mathrm{TR}=$ Total Penerimaan

$\mathrm{TC}=$ Total Biaya

4. Analisis R/C (Revenue Cost Ratio)

Revenue Cost Ratio merupakan suatu analisis yang digunakan untuk mengetahui keuntungan yang relatif pada usahatani. R/C Ratio dapat dihitung dengan menggunakan perbandingan antara penerimaan dengan biaya produksi yang dikeluarkan (Panjaitan et al., 2014)

Analisis R/C Ratio (Revenue Cost Ratio) dapat dihitung menggunakan rumus:

$$
\mathrm{RC}=\underline{\mathrm{TR}}
$$

TC

Keterangan:

$\mathrm{TR}=$ Total Penerimaan

$\mathrm{TC}=$ Total Biaya

Kriteria penerimaan $\mathrm{R} / \mathrm{C}$ ratio:

a) Jika R/C > 1, maka usahatani layak untuk diusahakan

b) Jika $\mathrm{R} / \mathrm{C}=1$, maka usahatani layak impas

c) Jika $\mathrm{R} / \mathrm{C}<1$, maka usahatani tidak layak untuk usaha. 


\section{HASIL DAN PEMBAHASAN}

Seorang petani sangat penting mempelajari ilmu usahatani kacang hijau agar dapat mengetahui tata cara memanfaatkan sumberdaya alam, karena usahatani merupakan ilmu yang mempelajari bagaimana seseorang mengalokasikan sumberdaya alam yang ada secara efektif dan efisien untuk tujuan memperoleh keuntungan yang tinggi pada waktu tertentu (Soekartawi, 2006).

Tingkat Produksi Kacang Hijau

Tingkat produksi kacang hijau yang di hasilkan setiap petani di Desa Gunung Sari Kecamatan Alok Kabupaten Sikka berkisaran dari 300Kg sampai dengan $900 \mathrm{Kg}$ dengan harga jual mulai dari Rp10.000-Rp13.000/Kg, sehingga jumlah keseluruhan produksi petani sebesar $20.900 \mathrm{Kg}$ dengan rata-rata $523 \mathrm{Kg}$ dan harga jual sebesar Rp492.000 dengan rata-rata sebesar Rp12.300.

1. Analisis Pendapatan

a. Biaya

Untuk mengetahui biaya-biaya yang dikeluarkan petani di Desa Gunung Sari Kecamatan Alok Kabupaten Sikka dapat dilihat pada tabel 1 berikut:

Tabel 1. Biaya-Biaya Produksi Petani Kacang Hijau

\begin{tabular}{cccc}
\hline No. & Uraian & Volume & $\begin{array}{c}\text { Harga Satuan } \\
\text { (Rp) }\end{array}$ \\
\hline $\mathbf{1}$ & Benih & Kg & 20.000 \\
\hline $\mathbf{2}$ & Pestisida & Liter & 75.000 \\
\hline $\mathbf{3}$ & Tenaga Kerja $(0.5 \mathrm{ha})$ & Jam & 20.000 \\
\hline $\mathbf{4}$ & Tenaga Kerja $(>1.0 \mathrm{ha})$ & Jam & 25.000 \\
\hline \multicolumn{2}{l}{ Sumber: Data Diperoleh Dari Responden }
\end{tabular}

Pengeluaran biaya pada benih perKg seharga Rp20.000, pengeluaran pestisida setiap liternya seharga Rp75.000 dan untuk upah tenaga kerja di luar rumah tangga berkisaran Rp20.000-Rp25.000 dilihat dari luas lahan dan jenis lahan yang digunakan petani kacang hijau di Desa Gunung Sari Kecamatan Alok Kabupaten Sikka.

2. Penerimaan dan Pendapatan Bersih

Total penerimaan dan pendapatan bersih setiap petani di Desa Gunung Sari pada Tabel 2 dan 3 berikut: 
Tabel 2. Penerimaan Petani Kacang Hijau (Ha 0.5-2.5)

\begin{tabular}{llcc}
\hline No & Keterangan & Total (Rp) & Rata-Rata (Rp) \\
\hline $\mathbf{1}$ & Produksi & 20.900 & 523 \\
\hline $\mathbf{2}$ & Harga Jual & 492.000 & 12.300 \\
\hline & Penerimaan & 259.050 .000 & 6.476 .250 \\
\hline
\end{tabular}

Sumber: Data Diperoleh Dari Responden

Tabel 3. Pendapatan Bersih Petani Kacang Hijau (Ha 0.5-2.5)

\begin{tabular}{llcc}
\hline No & Keterangan & Total (Rp) & Rata-Rata (Rp) \\
\hline $\mathbf{1}$ & Biaya Produksi & 14.292 .000 & 357.300 \\
\hline $\mathbf{2}$ & Penerimaan & 259.050 .000 & 6.476 .250 \\
\hline & Pendapatan Bersih & 244.738 .000 & 6.118 .450 \\
\hline
\end{tabular}

Sumber: Data Diperoleh Dari Responden

Jumlah produksi kacang hijau yang dihasilkan petani di Desa Gunung Sari sebesar $20.900 \mathrm{Kg}$ dengan rata-rata sebesar 523Kg, harga jual Rp492.000 dengan rata-rata sebesar $\mathrm{Rp} 12.300$, dan total penerimaan sebesar Rp259.050.000 dengan rata-rata Rp6.476.250.

Jumlah penerimaan petani dari hasil usahatani kacang hijau sebesar Rp259.050.000 dengan rata-rata Rp6.476.250, sedangkan jumlah biaya yang dikeluarkan adalah sebesar Rp14.292.000 dengan rata-rata Rp357.300. Jadi jumlah pendapatan bersih yang diperoleh petani kacang hijau di Desa Gunung Sari sebesar Rp244.738.000 dengan rata-rata Rp6.118.450.

\section{Analisis R/C Ratio}

Suatu usahatani dapat dikatakan menguntungkan apabila analisis nilai dari $\mathrm{R} / \mathrm{C}$ ratio lebih besar dari 1 sehingga usaha tani tersebut layak untuk di usahakan begitupun sebaliknya apabila nilai $\mathrm{R} / \mathrm{C}$ ratio kurang dari1 maka usahatani tersebut tidak layak untuk di usahakan. Jika nilai $\mathrm{R} / \mathrm{C}$ ratio sama dengan 1 , ini berarti usaha tani tersebut tidak menguntungan dan tidak merugikan. Nilai R/C ratio usahatani kacang hijau dari hasil penelitian di Desa Gunung Sari Kecamatan Alok Kabupaten Sikka memperoleh nilai sebagai berikut:

$$
\mathrm{R} / \mathrm{C} \text { ratio }=\frac{\mathrm{TR}}{\mathrm{TC}}=\frac{6.476 .250}{357.300}=18,12
$$

Dari hasil perhitungan tersebut, dapat diketahui bahwa rata-rata penerimaan setiap petani kacang hijau di Desa penelitian sebesar Rp6.476.250 dengan rata- 
rata biaya yang dikeluarkan untuk produksi kacang hijau sebesar Rp357.300, maka diperoleh nilai $\mathrm{R} / \mathrm{C}$ ratio sebesar 18,12 .

Hasil perhitungan analisis R/C ratio menunjukkan angka 18,12 atau lebih dari 1 yang berarti bahwa setiap satu rupiah yang dikeluarkan oleh petani kacang hijau dapat menghasilkan pendapatan sebesar 18,12 kacang hijau maka, usahatani tersebut menguntungkan sehingga usahatani tersebut baik untuk dikembangkan atau diteruskan.

4. Peran dan upaya petani

Peran dan upaya petani sangat di perlukan dalam meningkatkan hasil produktivitas tanaman kacang hijau. Pada dasarnya seorang petani harus memiliki pengetahuan. Agar mendapatkan pengetahuan yang baik, petani harus rajin/aktif mengikuti kegiatan penyuluhan yang dilakukan oleh dinas pertanian, agar pengetahuan tentang pembudidayaan kacang hijau yang baik dapat bertambah sehingga para petani dapat meningkatkan produksinya baik dari segi kualitas maupun kuantitas.

Adapun upaya yang dapat dilakukan petani dalam meningkatkan pendapatan usahatani yaitu:

a. Mengganti bibit kacang hijau yang lebih unggul/berkualitas

b. Semprot tanaman dengan obat pestisida

c. Bersihkan lingkaran pada tanaman kacang hijau

d. Lakukan pengecekan tanaman secara terus menerus

e. Memodifikasi lahan pertanian

f. Mengmanilisir biaya, artinya petani dapat melakukan atau mengurangi biaya-biaya yang dikeluarkan

\section{KESIMPULAN}

Berdasarkan hasil penelitian di Desa Gunung Sari Kecamatan Alok Kabupaten Sikka mengenai analisis pendapatan kacang hijau maka diperoleh kesimpulan sebagai berikut: 
1. Usahatani kacang hijau di Desa Gunung Sari dapat meningkatkan pendapatan petani. Adapun jumlah pendapatan bersih yang dihasilkan petani dari hasil penerimaan dengan nilai rata-rata sebesar Rp6.476.250 di kurangi dengan rata-rata total biaya yang dikeluarkan sebesar Rp357.300, sehingga total pendapatan yang diterima sebesar Rp6.118.950.

2. Berdasarkan usahatani kacang hijau yang di hitung dari $\mathrm{R} / \mathrm{C}$ ratio di Desa Gunung Sari dapat disimpulkan bahwa menguntungkan petani. Hal ini ditunjukan oleh hasil perbandingan diantara penerimaan dengan biaya $\mathrm{R} / \mathrm{C}$ ratio sebesar 18,12 yang berarti bahwa setiap Rp1 yang dikeluarkan oleh petani kacang hijau menghasilkan pendapatan Rp18,12.

Untuk memperoleh hasil yang berkualitas, para petani di Desa Gunung Sari di harapkan secara aktif mengikuti penyuluhan-penyuluhan yang dilakukan oleh pemerintah dibidang pertanian, agar pengetahuan tentang pembudidayaan kacang hijau dapat bertambah sehingga para petani dapat meningkatkan produksinya baik berupa kualitas maupun kuantitasnya.

\section{DAFTAR RUJUKAN}

Ambarsari et al. 2014. Analisis Pendapatan dan Protabilitas Usahatani Padi (Oryza Sativa). Kabupaten Indramayu. Jurnal Agri Wiralodra. 6.(2): 19-27

Kementerian Pertanian. 2012. Rencana Strategis Kementerian Pertanian Tahun 2010-2014. Edisi Revisi. Jakarta

Husni, A., K. Hidayah, Maskan. 2014. Analisis Finansial Usahatani Cabai Rawit di Desa Purwajaya Kecamatan Loa Janan. Jurnal Arifor. 13 (1): 49-52

Purwono, dan R. Hartono. 2005. Kacang Hijau. Penebar Swadaya. Jakarta

Rahim A., Dan Hastuti D. R. D. 2008. Pengantar, Teori, dan Kasus Ekonomika Pertanian. PS. Jakarta

Rodjak. (2006). Manajemen Usaha Tani. Bandung: Pustaka Gitaguna

Soekartawi. 2006. Analisis Usahatani. Jakarta: UI-Press. 110 hal

Sugiyono, 2009, Metode Penelitian Kuantitatif, Kualitatif dan R\&D, Bandung : Alfabeta

Syafruwardi, A., H. Fajeri dan Hamdani. 2012. Analisis Finansial Usahatani Padi Varietas Unggul. Desa Guntung Kalimantan Selatan. Jurnal Agrabisnis 2 (3): 181-192 
Wanda, F. F. E. 2015. Analisis Pendapatan Usahatani Jeruk Siam. Desa Padang Pangrapat Kabupaten Pasar. Jurnal Ilmu Administrasi Bisnis 3(3): 600-611 